\title{
Harnessing the Microbiome for Protein Production
}

\section{Edward A. Calt}

Executive Officer, Integrated BioChem, LLC. Raleigh, North Carolina USA 27617.

Corresponding author: Edward A. Calt, Executive Officer, Integrated BioChem, LLC. Raleigh, North Carolina USA.

Received date: March 16, 2021; Accepted date: April 13, 2021; Published date: July 07, 2021

Citation: Edward A. Calt, (2021) Harnessing the Microbiome for Protein Production. J, Biotechnology and Bioprocessing 2(6); DOI: 10.31579/2766-2314/034

Copyright: () 2021 Edward A. Calt. This is an open access article distributed under the Creative Commons Attribution License, which permits unrestricted use, distribution, and reproduction in any medium, provided the original work is properly cited.

\section{Abstract}

The microbiome of a ruminant animal rapidly converts cellulose into protein that is the true feed for the animal. Managed Ecosystem Fermentation (MEF) has harnessed this productive capacity into an industrial process. The MEF process rapidly converts cellulose, hemicellulose, carbohydrates, and starch into multiple products that have a wide range of applications in agriculture and industry. The protein produced has a complete amino acid profile and can be used as animal feed or for human consumption. Additionally, the protein contains lipids that contain Omega 3,6 and 9, and other food additives and flavorings. The MEF process can convert approximately one metric ton of cellulosic waste per cubic meter of fermentation vessel per day into protein. This paper describes the process, results from the pilot plant, and compares the protein produced to fishmeal and other protein sources. MEF offers a technology to convert a significant amount of biomass into proteins, lipids, and enzymes in a way that is both economically and environmentally sustainable.

Key Words: managed ecosystem fermentation, rumen, ruminant, microbial protein, microbial lipids, microbial enzymes

Multiple microbiomes exist within nature, each codependent upon the others. Microbiomes are complex systems that are difficult to analyze as many of the microbes are codependent upon each other and as such cannot be isolated. However, this does not mean that an understanding of the process cannot be ascertained and/or controlled. For example, we do not fully understand the human microbiome, yet we are able to figure out what we can and cannot eat. And as such we are able to ascertain various parameters about which our own microbiome functions. With this understanding we are able to conduct our daily lives. If we view a microbiome from this perspective, then we can exert some control over it.

Microbiomes operate within a defined set of principles that dictate its behavior and hence its output. A microbiome must have an external source of food (carbon), energy, nutrients and water. There is an energy pyramid within the microbiome where several species consume the external material and generate a waste stream. In doing so, these microbes take the material with the highest energy density and break it down and then expel it as a waste that has a lower energy density. This waste stream becomes the food source for other microbes within the microbiome. This process repeats itself until there is a way to expel the lowest energy material produced from the microbiome. A basic law of nature, which states no species can survive in its own waste stream, confirms this. These principals provide the basis for the industrializing a specific microbiome.

Both natural and managed microbiomes share several common traits. First, microbiomes are symbiotic. Each microbe is dependent upon its relationships with other microbes as well as its host environment. Second, natural microbiomes do not require a sterilized food source. Humans and animals do not require a sterilized food source. Their digestive microbiomes have evolved to protect the host. Essentially, most pathogens find an adversarial microbe within the ecosystem to consume it. Microbiomes have a wide range of materials that can be used as a food source. This permits them to survive for years at a time and is illustrated by the variety of food we eat. Third, microbiomes are focused on their own survival. This means they will adapt to changes in the environment in a way that ensures its survival. Finally, a microbiome works because a multispecies system has more chemical pathways to breakdown the biomass that any single species.

The microbiome in most animals simply break down the food so as to enable the subsequent utilization within the animal. The microbiome of a ruminant animal is unique in that it converts 
cellulosic biomass into the food (i.e. protein, enzymes, lipids, and volatile fatty acids) for its host. This microbiome employs over 3,000 species of bacteria, yeast, fungi, and protozoa. This consortium of microbes converts cellulosic biomass into the protein, amino acids, lipids and volatile fatty acids that are the true food for the host animal. This consortium of microbes is able to efficiently convert cellulose into protein. This efficiency is derived from the microbe's ability to generate over $30,000^{\text {ii }}$ enzymes that facilitate the decomposition in an energy efficient manner. This microbiome was designed by nature to rapidly convert cellulosic biomass into protein for the animal.

The ruminant microbiome conforms to the basics of microbiology. First, all cells require a source of carbon, nitrogen, phosphorous, and a variety of inorganic ions. Second, if there is a sufficient amount of nutrients available, growth and reproduction occur. Under optimal conditions, the microbes can double in number every 20 to 30 minutes. Third, microbes derive their energy in various ways. Some use oxidation or reduction of inorganic compounds. Others use the energy from the carbon compounds that are available. Finally, microorganisms are extremely adaptable to changes in their environment and food supply. Changes in the environment or food supply may cause the entire microbiome to change within one generation in order to survive. These elements provide the basis for the industrialization of the ruminant microbiome.
The ability of a ruminant's microbiome to rapidly produce protein has been studied in detail by the beef and dairy industries to ascertain how to put more meat on the bone and/or get more milk from the cow. This is the same process which Integrated BioChem, LLC has industrialized. There are differences between what has been studied and the Managed Ecosystem Fermentation (MEF) process. First, the MEF process has multiple levers that can be managed to change the composition of the protein and lipids produced.

Second, the microbiome of the ruminant changes once it is freed from the control systems inherent with the ruminant animal. This enables the implementation of methods that enable the management of the process. Third, unlike most industrialized bioprocesses, MEF is a very adaptive system that can deal with changes in its food, environment, and handling. Essentially, it is an adaptive system.

Within the rumen organ the cellulosic matter is continually mixed. This mixing serves several functions. First, it moves the digested matter and microbial protein produced on through the digestive tract. Second, it facilitates the transference of the microbes on to the new feed. This enables a continuous system. This also enables the expelling of the non-digestible matter.

In the MEF process, advantage is taken from the unique property of the process to self-separate. This enables the ease of mixing and separation. In Figure 1 this separation can be seen.

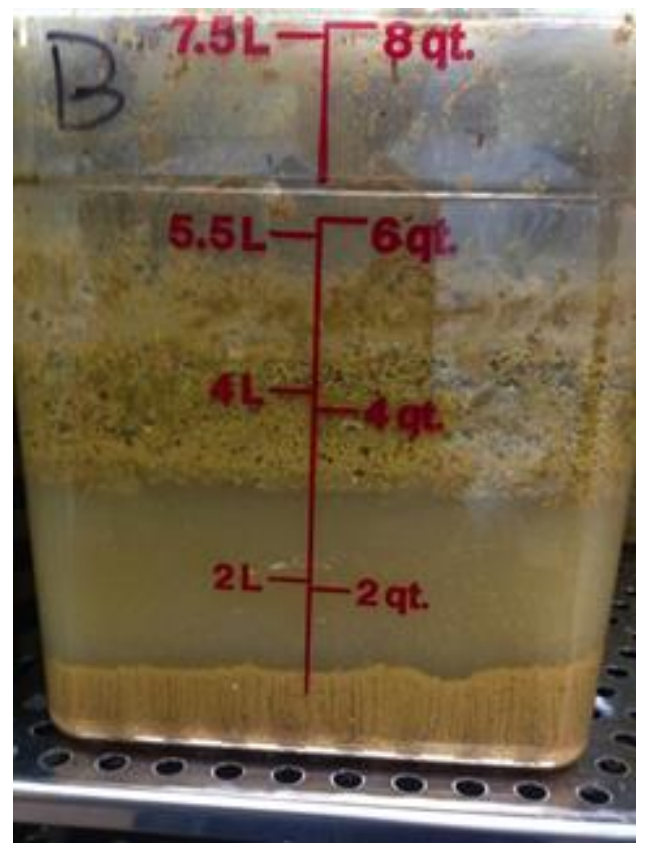

Figure 1. Managed Ecosystem Fermentation

Most of the biological activity occurs at the interface of the top mat and middle layer. There is a continuous circulation between the bottom and top mat. This recirculation is the exchange of nutrients and undigested matter between the various microbes.
After the microbes have had sufficient time to consume the feedstock, the protein that is in the bottom is harvested.

On an industrial basis the production equipment would look something like Figure 2, which is the MEF process run at a pilot 
plant scale. The MEF pilot plant was run using 2 200-liter reactors. In this operation the process had a cycle time of 24 hours. In fullscale production the cycle time would be about 8 hours. This means a reactor would be harvested 3 times per day. There would be a number of fermentation vessels. The number of vessels would be determined by the availability and digestibility of the feedstock.

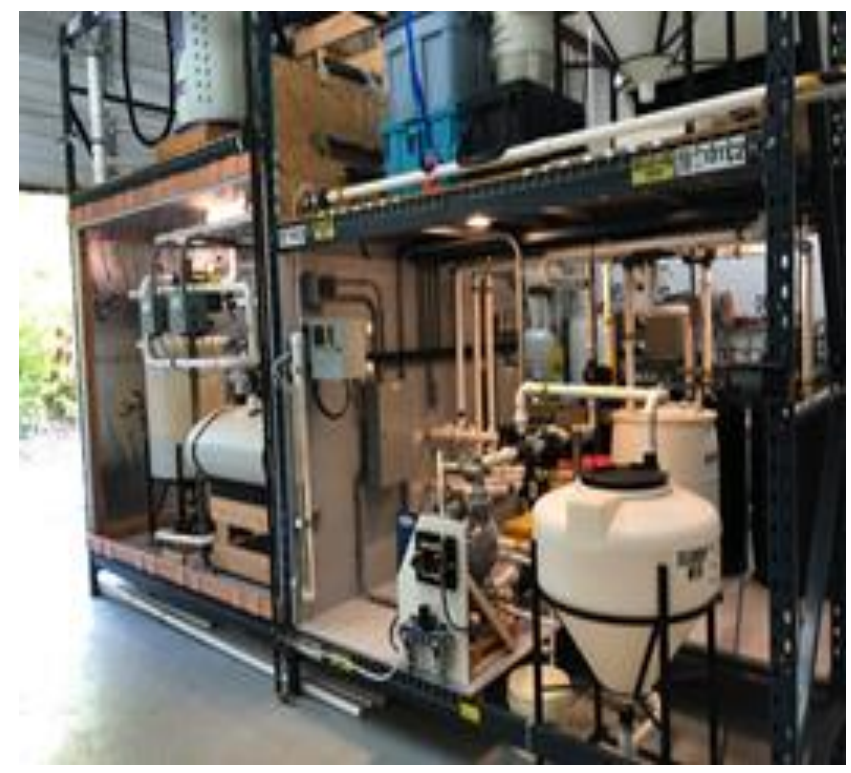

Figure 2. MEF Pilot Plant

The MEF process is capable of processing about 1 metric ton of food waste per cubic meter of fermenter per day. The current design specifications call for fermentation vessels with 5 cubic meters of fermentation capacity. The available inbound tonnage of feedstock would be divided by 5 to ascertain the number of fermentation vessels needed for the process for a particular site.

The processing of food waste using the MEF process is consistent with that seen in the ruminant animal. On a dry matter basis, about
$50 \%$ of the biomass will be converted into methane $(30 \%)$ and carbon dioxide (20\%). These gases are reused within the process. About $25 \%$ will come out as a protein and the remaining balance will be composed of volatile fatty acids and non-digestible matter.

From this process the protein is extracted and dried. It is pictured in Figure 3.

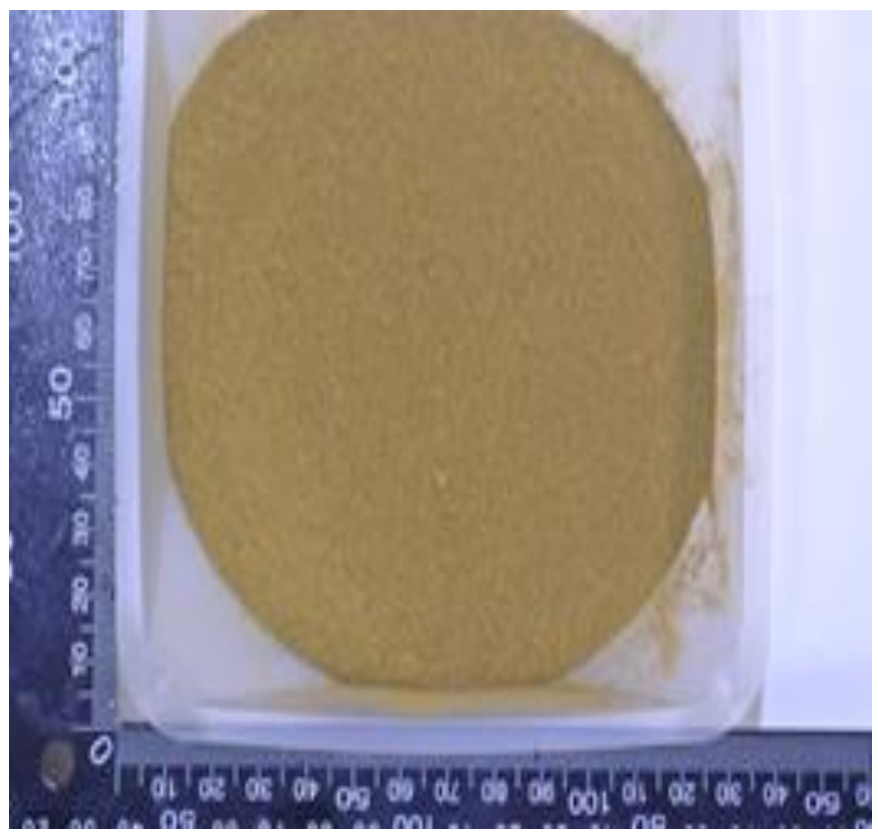

Figure 3. $M E F$ Protein 
The protein is a dry, stable, sterile powder that can be incorporated into animal feed or be denatured for other industrial applications.

Raw MEF protein is the material that would be produced from the fermentation process after drying. Denatured MEF protein has had some of the lipids extracted from the raw MEF protein using a solvent that is used in food processing today. The numbers provided for the raw MEF and denatured protein are from an Independent Laboratory ${ }^{\mathrm{iii}}$.

The protein produced is comparable to fish caught in the ocean and used to produce fishmeal. Table 1 shows the results of the protein produced from the pilot plant as compared to open ocean fish.

\begin{tabular}{|c|c|c|c|}
\hline \multicolumn{2}{|c|}{ Species } & $\begin{array}{c}\% \text { Protei } \\
\text { n }\end{array}$ & $\%$ Fat \\
\hline \multicolumn{2}{|l|}{ Anchovies } & 18 & 6 \\
\hline \multicolumn{2}{|c|}{ Herring (winter) } & 18 & 11 \\
\hline \multicolumn{2}{|c|}{ Herring (spring) } & 18 & 8 \\
\hline \multicolumn{2}{|l|}{ Pilchard } & 18 & 9 \\
\hline \multicolumn{2}{|c|}{ Mackerel (autumn) } & 15 & 27 \\
\hline \multicolumn{2}{|c|}{ Mackerel (spring) } & 18 & 6 \\
\hline \multicolumn{2}{|c|}{ Horse mackerel } & 16 & 17 \\
\hline \multicolumn{2}{|l|}{ Capelin } & 14 & 10 \\
\hline \multicolumn{2}{|c|}{ Blue whiting } & 15 & 2 \\
\hline \multicolumn{2}{|l|}{ San eel } & 18 & 7 \\
\hline \multicolumn{2}{|l|}{ Sprat } & 15 & 8 \\
\hline \multicolumn{2}{|r|}{ Average } & 16.6 & 10.1 \\
\hline \multirow{2}{*}{$\begin{array}{c}\text { Raw MEF } \\
\text { Protein }\end{array}$} & Laboratory & 26.00 & 31.36 \\
\hline & Pilot Plant & 18.60 & 8.95 \\
\hline
\end{tabular}

\section{Table 1 Raw Fish vs MEF Protein}

The primary reason for the fat content being lower in the pilot plant is the inbound temperature of the feedstock was too low. This meant the microbes needed to consume the fat/lipids that would normally have been stored in the microbial cell.

These results suggest that microbial protein can be used as an alternative to fishmeal. When comparing the raw fish to fishmeal it is necessary to understand how fishmeal is produced. The raw fish are cooked, ground, and then pressed to extract the fish oil. This leaves a higher protein content with less of the various fatty acids. This is a semi-denatured product, which can be compared to the MEF protein that has been denatured using a solvent that is used in the food industry. This comparison is shown in Table 2.

\begin{tabular}{|l|c|c|c|}
\hline \multicolumn{4}{|c|}{ Table 2 } \\
\hline \multicolumn{3}{|c|}{ Fishmeal $^{\text {iv }}$ Vs Denatured MEF Protein } \\
\hline Description & $\begin{array}{c}\text { Average } \\
\text { \% }\end{array}$ & $\begin{array}{c}\text { Minimum } \\
\text { \% }\end{array}$ & $\begin{array}{c}\text { Maximum } \\
\text { \% }\end{array}$ \\
\hline & \multicolumn{3}{|c|}{ Protein Content } \\
\hline Fishmeal & 72 & 68 & 74 \\
\hline MEF & \multicolumn{3}{|c|}{ Oil \& Fat Content } \\
\hline & \multicolumn{3}{|c|}{ Ash Content } \\
\hline Fishmeal & 8 & 5 & 10 \\
\hline MEF & \multicolumn{3}{|c|}{6.14} \\
\hline & \multicolumn{3}{|c|}{ Moisture Content } \\
\hline Fishmeal & 7 & 4 \\
\hline MEF & \multicolumn{3}{|c|}{10} \\
\hline & 7 & 3.27 \\
\hline Fishmeal & \multicolumn{3}{|c|}{} \\
\hline MEF & \multicolumn{3}{|c|}{} \\
\hline
\end{tabular}


Table 2 illustrates that the MEF protein is comparable to fishmeal. It is only how the denaturing process is managed that dictates the protein and fat content in the dry powder. In the above sample it contained about $14 \%$ oil and fat, which lowered the protein content on a mass balance basis.

Additionally, the MEF protein compares similarly to other animal based protein as shown in Table 3. Tables 1, 2, and 3 illustrate both the range of values but also show that the MEF protein can be altered to meet the specifications desired for commercial purposes.

\begin{tabular}{|l|c|c|c|c|}
\hline & Percent Per 100g of Meat & \multirow{2}{*}{$\begin{array}{c}\text { Kcal per } \\
\mathbf{1 0 0} \text { g }\end{array}$} \\
\cline { 1 - 3 } Source & Water & Protein & $\begin{array}{c}\text { Total } \\
\text { Lipid }\end{array}$ & \\
\hline Goat & 68.21 & 27.10 & 3.03 & 143 \\
\hline Lamb & 57.48 & 25.55 & 16.48 & 258 \\
\hline Pork & 60.66 & 29.41 & 9.44 & 211 \\
\hline Beef & 64.46 & 27.42 & 7.72 & 187 \\
\hline Veal & 67.01 & 28.07 & 3.39 & 150 \\
\hline Chicken & 62.10 & 23.97 & 13.39 & 233 \\
\hline \multicolumn{2}{|r|}{ MEF Protein } & & & \\
\hline Laboratory & 14.75 & 26.00 & 31.36 & 512 \\
\hline Pilot Plant & 9.27 & 22.85 & 7.19 & 363 \\
\hline Denatured & 3.27 & 61.48 & 13.81 & 515 \\
\hline
\end{tabular}

Nutritional Comparison

Table 3. MEF vs Mammal \& Foul

Some of the lipids produced are shown below in Table 4 along with their industrial applications.

\begin{tabular}{|l|l|}
\hline Description & Applications \\
\hline Palmitic acid & Soaps, cosmetics and mold release agents \\
\hline Stearic acid & $\begin{array}{l}\text { Soaps, cosmetics, detergents, lubricants, softening and release } \\
\text { agents }\end{array}$ \\
\hline Oleric acid & $\begin{array}{l}\text { Form of Omega } 9 \text { food additive, emulsifying agent, emollient, } \\
\text { pharmaceuticals }\end{array}$ \\
\hline Linoleic acid & $\begin{array}{l}\text { Form of Omega } 6 \text { food additive, quick-drying oil, paint, } \\
\text { varnish, surfactant, cosmetics }\end{array}$ \\
\hline$\alpha$-Linolenic acid & Pharmaceutical \\
\hline Gamma Linolenic acid & Form of Omega 6 food additive, pharmaceutical \\
\hline Stearidonic acid & Form of Omega 3 food additive, pharmaceutical \\
\hline Docosatetraenoic acid & Form of Omega 6 food additive, pharmaceutical \\
\hline Docosapentaenoic acid n3 & Form of Omega 3 food additive, pharmaceutical \\
\hline Docosahexaenoic acid & Form of Omega 3 food additive \\
\hline Ceramide & Soaps, cosmetics and mold release agents \\
\hline
\end{tabular}

Table 4. Lipids Extracted From MEF Protein

In commercial production the fish oil is sold either for human consumption or reincorporated into the animal feed to a desired level. In the MEF process these oils are extracted using the same solvents that are used in processing soybean and vegetable oils.
The results from the separation process are seen in Figure 4. The difference between the 2 separations is the solvent used.

While Table 4 shows the commercial application, from a nutrition perspective the critical compounds are the Omega fatty acids. 


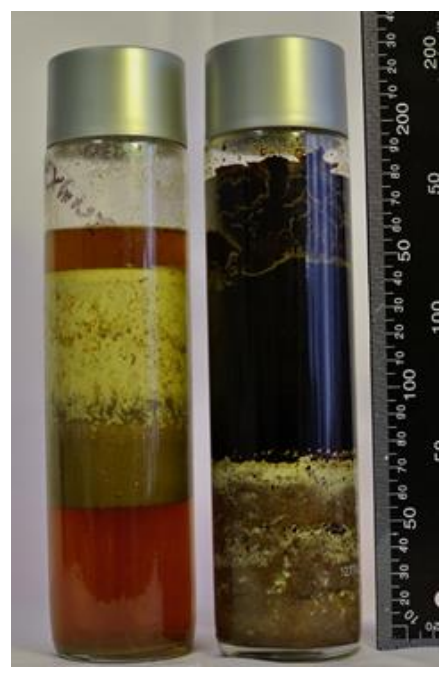

Figure 4. MEF Lipids Separated

One of the critical aspects of these lipids is they are selfseparating. This means that with existing food processing technology the lipids can be separated and then recombined into any desired formulation. Of particular interest would be the separation of the phospholipids that can be sold to the pharmaceutical or cosmetic industries.

These lipids are also common in other foods we consume that originate in a ruminant animal.

\begin{tabular}{|c|c|c|c|c|c|c|c|c|c|c|c|c|c|}
\hline Cheese Type & $\mathrm{C}_{2.0}$ & $\mathrm{C}_{4.0}$ & $\mathrm{C}_{6.0}$ & $\mathrm{C}_{8.0}$ & $\mathrm{C}_{10.0}$ & $\mathrm{C}_{12.0}$ & $\mathrm{C}_{14.0}$ & $\mathrm{C}_{16.0}$ & $\mathrm{C}_{18.0}$ & $\mathrm{C}_{18.1}$ & $\mathrm{C}_{18.2}$ & $\mathrm{C}_{18.3}$ & Total \\
\hline Parmesan & & 1055 & 451 & 243 & 440 & 439 & 1540 & 3896 & 1171 & 3471 & 123 & & 13,697 \\
\hline \multirow[t]{3}{*}{ Cheddar } & 476 & 952 & 143 & 175 & 159 & 571 & 952 & 1556 & 794 & 2841 & 635 & 238 & 9,492 \\
\hline & 1587 & 952 & 191 & 159 & 175 & 619 & 746 & 1253 & 508 & 1476 & 413 & 175 & 8,254 \\
\hline & 1270 & 794 & 111 & 111 & 48 & 238 & 397 & 619 & 270 & 667 & 206 & 111 & 4,842 \\
\hline \multirow[t]{2}{*}{ Swiss } & & 170 & 90 & 45 & 122 & 208 & 311 & 1904 & $1427^{\mathrm{a}}$ & & & & 42,77 \\
\hline & & 345 & 21 & 25 & 53 & 88 & 267 & 930 & $119^{a}$ & & & & 2,926 \\
\hline Edam & & 60 & 8 & 9 & 14 & 47 & 39 & 122 & $57^{\mathrm{a}}$ & & & & 356 \\
\hline Mozzarella & & 54 & 7 & 1 & 120 & 12 & 27 & 76 & $66^{\mathrm{a}}$ & & & & \\
\hline \multirow[t]{3}{*}{ Camembert } & & 35 & 5 & 14 & 35 & 43 & 69 & 270 & $210^{\mathrm{a}}$ & & & & 681 \\
\hline & 208 & 101 & 52 & & & & 448 & 1028 & & 1421 & & & \\
\hline & & 361 & 287 & 160 & 225 & 298 & 622 & 1442 & 303 & 1043 & & & \\
\hline Roquefort & & 961 & 626 & 707 & 2280 & 1295 & 3185 & 6230 & 2241 & 6282 & 896 & & 25,969 \\
\hline Port Salut & & 41 & 4 & 8 & 54 & 33 & 86 & 275 & $199^{\mathrm{a}}$ & & & & 700 \\
\hline Limburger & & 1475 & 688 & 24 & 50 & 92 & 602 & 565 & $709^{a}$ & & & & \\
\hline Münster & & 163 & 102 & 66 & 154 & 206 & 704 & 2057 & 833 & 1412 & 58 & 504 & \\
\hline
\end{tabular}

Table 5. Concentration ( $\mathrm{mg} / \mathrm{kg}$ cheese) of free fatty acids in some selected cheese varieties [6]

The lipids produced from the MEF process are the same as those that provide the distinctive flavor to various cheeses. In Table 5 these lipids and volatile fatty acids are identified in blue.

Table 5 shows that the lipids in the milk originate in the microbiome within the rumen organ. Controlling the exposure to various gases can increase the lipid content in the protein.

"Bacteria are known to produce a range of microbial oils that have multiple applications in industry. The production of these microbial oils has not been limited by the lack of desire for the end products, but simply by the absence of an appropriate means of producing microorganisms on a sufficiently large scale"v. MEF now makes the production of microbial protein and lipids possible using existing production equipment, facilities and feedstocks, at a profit needed to provide the required economic return.

In most settings, the MEF process will be housed in a building with an insulated fermentation chamber to maintain the temperature needed to sustain the process. The building, fermentation chamber, tanks pumps, separation, drying and bagging equipment are all fixed costs. This is where the largest cost element of the process will be incurred in the form of depreciation. The estimated cost of production of one metric ton of MEF protein is approximately $\$ 600$ or less. This assumes that the feedstock is either free or at nominal cost. In most cases the MEF processing facilities will be collocated with industries that have high volumes of waste cellulosic biomass. The biomass will 
be pumped at no cost to the MEF process as the biomass generator receives the benefit of a reduced disposal cost. If the feedstock is a food waste, then the cost of nutrients per metric ton of feedstock is about $\$ 2.00$. The MEF process is automated to the extent that personnel will be required in three areas; the process control, inbound feedstock preparation, and packaging and shipping. The facilities are expected to operate 24 hours per day, 7 days per week. As the MEF protein is in a dry powdered form, the shipping cost to the buyer should be minimal.

The MEF process addresses to growing needs in both the developed and developing world. The need to dispose of the waste biomass we generate every day is the first. The second is the need for a new source of protein. The MEF process is a technology that enables the production of protein and lipids in an economical and sustainable manner.

\section{Conclusion}

The MEF process has replicated the first stomach of a herbivore. In the animal, the microbial protein produced is subsequently digested and converted into the meat we see in the supermarket. This implies that the microbial protein produced by the process can be used as a substitute for protein derived from the flesh of animals. The data derived from the independent laboratory analysis as compared to other animal protein studies confirm that this position. This means by processing waste organic matter with the MEF process, a new sustainable source of protein for multiple applications is now available. Initial applications would include inclusion in animal feed, and biodegradable adhesives.
In developing the MEF process a number of design/operating advantages were pointed out by plant manages from several local biotech companies. First, the process avoids all the cost associated with sterilization. Second, the protein is self-separating. Third, the process can rapidly adapt to changes in the feedstock. Finally, the MEF process provides a processing capacity that is not inherent in other anaerobic digestion processes. MEF can process about one metric ton of food waste per cubic meter of reactor per day. This is because the microbial culture doubles every twenty minutes.

In summary, the MEF process provides a new sustainable source of protein while simultaneously addressing the issues associated with organic waste disposal. Essentially, it converts a waste stream into a revenue stream of high value compounds that have application in multiple industries.

\section{References}

1. The Rumen and Its Microbes by Robert E. Hungate, (1966) Academic Press.

2. The US Department of Energy estimates there are over 30,000 enzymes in the fermentation broth. DOE website: "How now, inside the cow? 30,000 enzymes for biofuel".

3. Carolina Analytical Services, LLC., Bear Creek, North Carolina

4. The Evaluation of Functional Properties of Fishmeal. S, Ariyawansa, (2000). Icelandic Fisheries Laboratories.

5. Quality Fish Meal: Specifications and Use in Aquaculture Farming, N. Jensen, Esbjerg Fiskeindustri (1990) International By-Products Conference, Anchorage Alaska.

6. Ratledge C.(1994), Technological Advances In Improved And Alternative Sources Of Lipids, Page 238, Blackie Academic \& Professional 1994 